\title{
The Relationship Between Blood and Fertility Parameters in Post Partum Dairy Cows
}

\author{
By J. Eldon, Th. Olafsson and Th. Thorsteinsson
}

\begin{abstract}
Eldon J., Th. Ólafsson and Th. Thorsteinsson: The relationship between blood and fertility parameters in post partum dairy cows. Acta vet. scand. 1988, 29, 393399. - The onset of post partum ovarian activity, the number of artificial inseminations (AI) and the time of conception were monitored in 412 Icelandic dairy cows during a period of 3 years. Blood was sampled from the animals at various times after calving and the serum concentration of glucoce, urea, calcium $(\mathrm{Ca})$ and magnesium $(\mathrm{Mg}$ ) measured. A significant positive correlation was found between the levels of glucose, urea and $\mathrm{Ca}$ and the number of days from calving.

A significant negative correlation was found between the level of urea and the time of first post partum ovulation. A significant positive correlation was found between the level of glucose and the time of conception. No correlation was found between the blood parameters and the number of AI per animal, the length of first post partum ovarian cycle or the ammount of progesterone found during that cycle.

A distinct, although not statistically significant, tendency towards a negative correlation between the level of glucose and the time of first post partum ovulation was found.

Our results show that the levels of glucose and urea shortly after parturition do indicate the time of onset of post partum ovarian cyclicity.

Our findings indicate that low blood glucose and urea values early post partum lead to subclinical or clinical ketosis which can considerably delay the onset of ovarian activity.
\end{abstract}

glucose; calcium; magnesium; urea; ketosis.

\section{Introduction}

McClure (1968) and Butler et al. (1981) maintain that negative energy balance i.e. low serum glucose, does affect the post partum reproductive performance of dairy cows. High dietary protein has, on the other hand, been said to have detrimental effect on the reproductive performance of dairy cattle (Morrow et al. 1969, Howard et al. 1987).

In previous studies we observed a later onset of post partum ovarian activity ( $x=42$ days) in Icelandic dairy cows than observed in other breeds (Eldon et al. 1985, Eldon \& Ólafsson 1986). As ketosis is endemic in a few areas in Iceland, and milk fever and grass tetany are common disturbances in Icelandic dairy cattle (Olafsson et al. 1974, Sigurdarson \& Thorsteinsson 1978, Bjarnason 1986) we undertook this study to look for any apparent relationship between the levels of glucose, urea, $\mathrm{Ca}$ and $\mathrm{Mg}$ in blood and the reproductive performance of the Icelandic dairy cow.

\section{Material and methods}

The serum values of glucose, urea, $\mathrm{Ca}$ and $\mathrm{Mg}$ were monitored and related to the time of first post partum ovulation, the number of AI, the time of conception and the dura- 
tion and amplitude of the first ovarian cycle in 412 Icelandic dairy cows during a period of 3 years. Sequential milk samples for progesterone measurements were taken every 5 th day from day 10 post partum until the time of first post partum AI and blood samples were taken 1-4 times at various intervals post partum from each cow.

Progesterone was assayed in the fat-free part of the milk by a radioimmunoassay technique using tritiated progesterone and charcoal as described by Oltner \& Edqvist (1980, 1981) and Eldon \& Ólafsson (1986). The bloot parameters were determined by conventional methods. Glucose and urea were assayed in a Technicon Auto Analyser II and $\mathrm{Ca}$ and $\mathrm{Mg}$ were determined in a Perkin-Elmer 305 B Atomic Absorption Spectrophotometer (Eldon et al. 1987).

Statistical analysis was carried out with the SPSS-X statistical program in a Vax 750
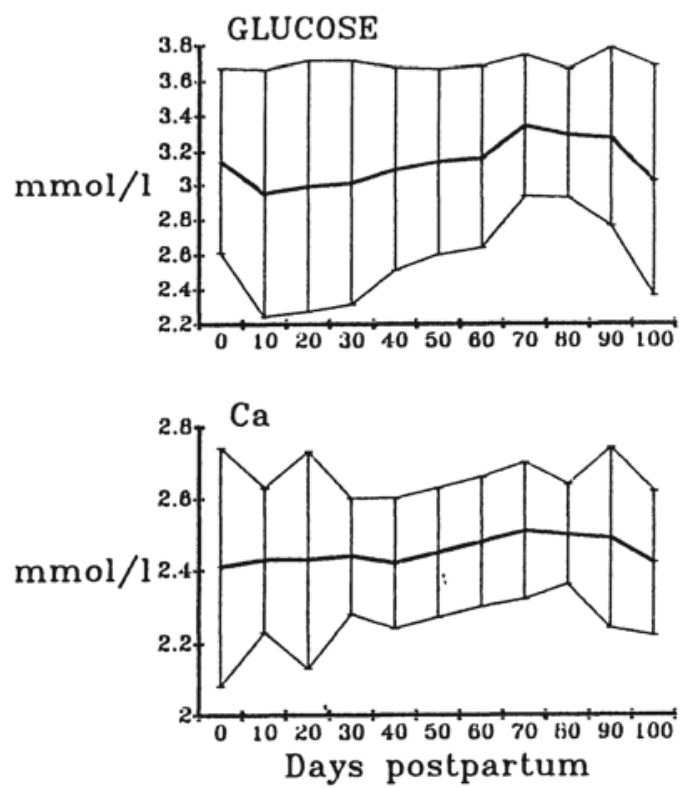

computer. The methods used were regression analysis and one-way analysis of variance (ANOVA).

\section{Results}

There was a significant positive correlation between the values of glucose, urea and $\mathrm{Ca}$ and the number of days from calving (Table 1). Fig. 1 shows how the average values of the blood parameters change with increasing time from calving. The level of glucose decreased from calving until 10 days post partum and then slowly increased until 70 days post partum when the values levelled off. A sharp decrease was seen in samples taken 90 days post partum or later. These samples, taken 90 days post partum or later, came from anoestrous cows.

The mean values of urea, $\mathrm{Ca}$ and $\mathrm{Mg}$ were lowest immediatly after calving. The urea and $\mathrm{Ca}$ values increased until 90 days post
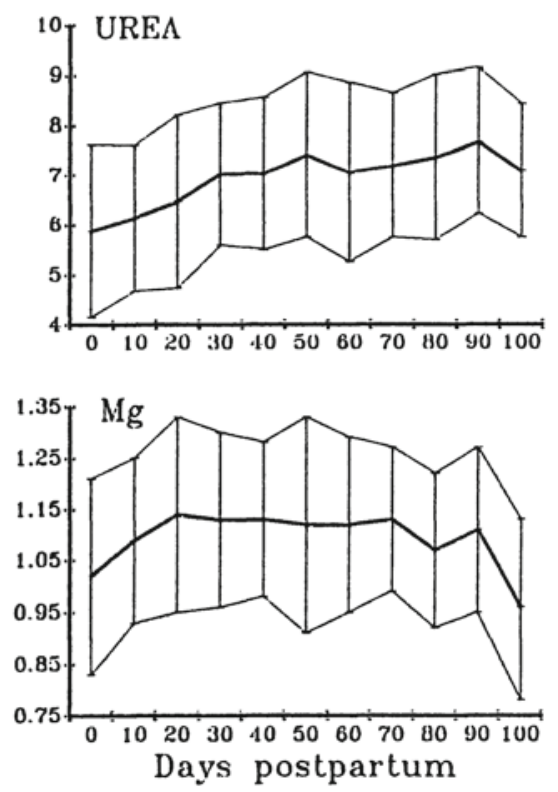

Figure 1. The changes of blood levels of glucose, urea, calcium $(\mathrm{Ca})$ and magnesium $(\mathrm{Mg})$ with increasing time from calving. The horizontal black curve shows the mean values for each 10 day interval and the vertical lines show the deviation from the mean of 1 standard deviation. 


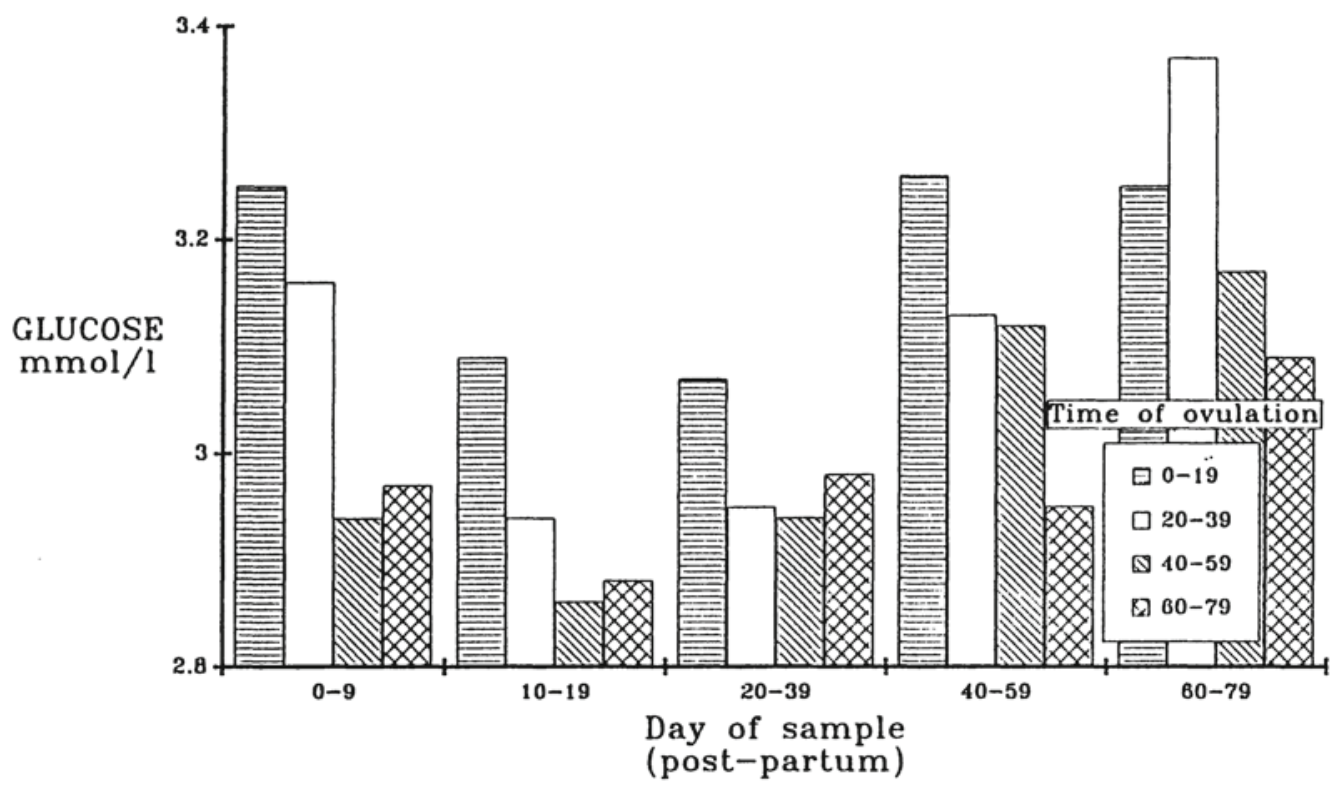

Figure 2. The changes in the blood levels of glucose with increasing time of first post partum ovulation. The results are divided into two 10 days sampling periods (samples taken 0-9 and 10-19 days post partum) and 320 days sampling periods (samples taken 20-39, 40-59 and 60-79 days post partum). Each sampling period shows the mean values of glucose according to 20 day periods of the time of first post partum ovulation.

partum and decreased hereafter. The mean values of $\mathrm{Mg}$ increased sharply during the first 20 days post partum, levelled off and dropped in samples taken 90 days or later post partum (Fig. 1).

Fig. 2 shows the changes in the blood levels of glucose in relation to increasing time of first post partum ovulation. The values decreased with increasing time to first post partum ovulation. This correlation was not statistically significant but points clearly to a negative correlation.

A significant positive correlation was found between the level of urea and the time of first post partum ovulation (Table 1). Fig. 3 shows how the urea values changed with increasing time of first post partum ovulation. In samples taken 0-9 and 10-19 days post partum the values decreased with increasing time of first post partum ovulation, but in
Table 1. Correlation coefficients and levels of significance for the correlations between reproductive and blood parameters.

\begin{tabular}{lclll}
\hline Category & Glucose & Urea & $\mathrm{Ca}$ & $\mathrm{Mg}$ \\
\hline 1 & $0.11^{* *}$ & $0.25^{* * *}$ & $0.09^{*}$ & $0.01 \mathrm{~ns}$ \\
2 & $-0.02 \mathrm{~ns}$ & $0.20^{* *}$ & $0.05 \mathrm{~ns}$ & $0.05 \mathrm{~ns}$ \\
3 & $0.11^{*}$ & $0.06 \mathrm{~ns}$ & $0.06 \mathrm{~ns}$ & $0.07 \mathrm{~ns}$ \\
4 & $0.05 \mathrm{~ns}$ & $0.04 \mathrm{~ns}$ & $0.01 \mathrm{~ns}$ & $0.06 \mathrm{~ns}$ \\
5 & $0.02 \mathrm{~ns}$ & $-0.01 \mathrm{~ns}$ & $0.05 \mathrm{~ns}$ & $-0.01 \mathrm{~ns}$ \\
6 & $0.03 \mathrm{~ns}$ & $-0.01 \mathrm{~ns}$ & $0.09 \mathrm{~ns}$ & $-0.01 \mathrm{~ns}$ \\
\hline
\end{tabular}

1. Time from calving to sample

2. Time of first post partum ovulation

3. Time of conception

4. Number of AI

5. The length of the first post partum ovarian cycle

6. The highest progesterone value assayed during the first post partum ovarian cycle

$\mathrm{ns}=$ not significant $(\mathrm{p}>0.05),{ }^{*}=(\mathrm{p}<0.05),{ }^{* *}=$ $(\mathrm{p}<0.01),{ }^{* * *}=(\mathrm{p}<0.001)$. 


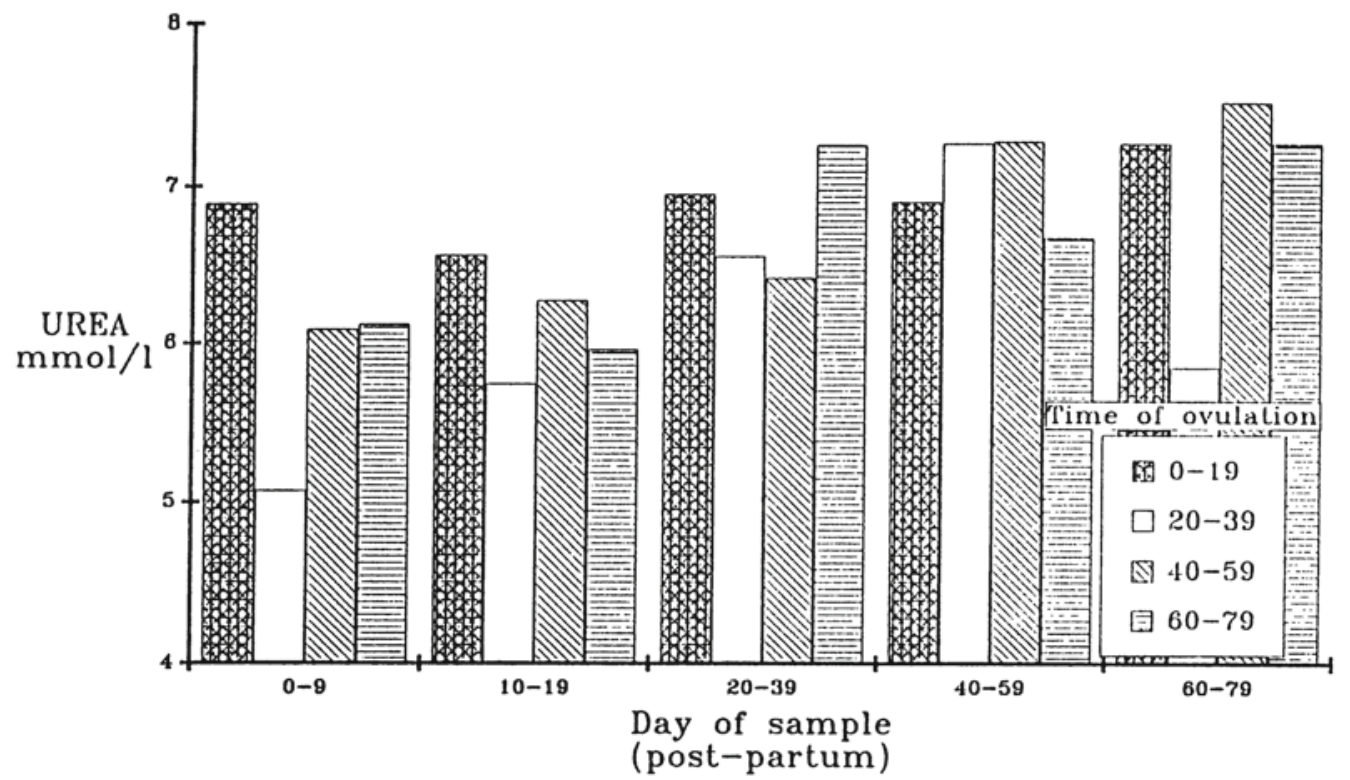

Figur e 3. The changes in the blood levels of urea with increasing time of first post partum ovulation. See legend for Fig. 2.

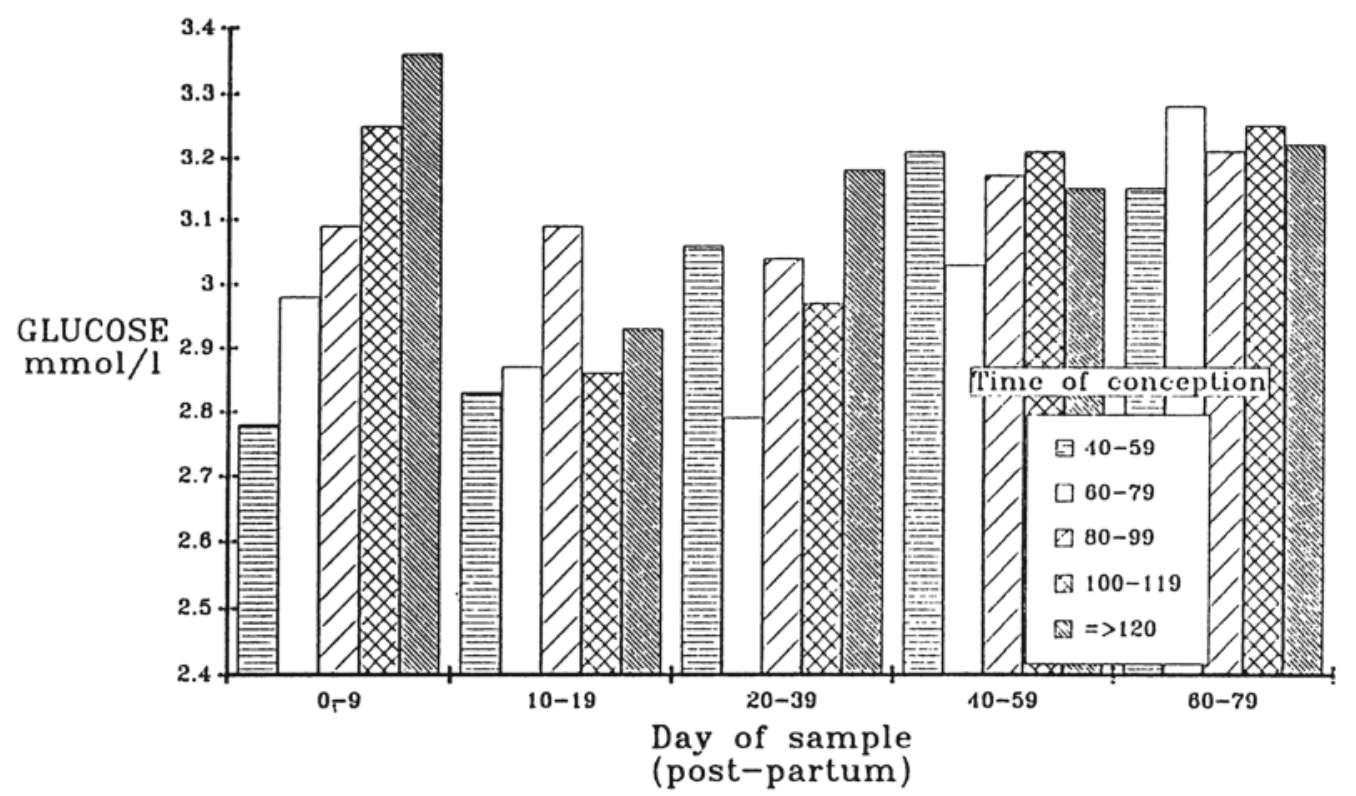

Figure 4. The changes in the blood levels of glucose with increasing time of conception. See legend for Fig. 2. 
samples taken 20 days or later post partum the values of urea increased with increasing time of ovulation. A significant positive correlation was found between the levels of glucose and the time of conception (Table 1). Fig. 4 shows that this correlation was most prominent in samples taken 0-9 days post partum.

Significant correlation was not found between the blood parameters and the number of AI per animal, length of first post partum ovarian cycle or the amplitude of progesterone during that cycle. No correlation was found between levels of $\mathrm{Mg}$ and the reproduction parameters.

\section{Discussion}

The changes in glucose values found in our study are similar to those observed by Kappel et al. (1984) who reported that average plasma glucose increased before calving and then decreased to a minimum value between 11 and 25 days post partum.

The low mean values of urea, $\mathrm{Ca}$ and $\mathrm{Mg}$ found early post partum were probably caused by the metabolic strain of late gestation, parturition and onset of milking (Saarinen 1950, Payne \& Leech 1964, Tainturier et al. 1984).

The urea values correlated significantly with the time of first post partum ovulation. This correlation was negative for samples taken the first 20 days post partum but positive after that which is in accord with the findings of Morrow et al. (1969) that cows fed liberal concentrate ratio had significantly longer calving intervals and required more services per conception than controls, whereas $\mathrm{Ho}$ ward et al. (1987) stated that high dietary protein did not have a detrimental effect on reproductive performance of dairy cows. A possible cause of low blood urea values early post partum in late ovulating cows is a negative protein balance due to parturient stress and onset of milking. A possible cause of high blood urea late post partum in late ovulating cows is a high protein diet whith toxic ammonia effects on the reproductive system (Morrow et al. 1969, Visek 1984, Howard et al. 1987).

The observed finding towards a negative correlation between glucose levels and the time of first post partum ovulation are in accord with the findings of Butler et al. (1981) who stated that the interval from parturition to first normal ovulation was inversely related to average energy balance during the first 20 days of lactation. The mean glucose values decreased for the first 10 days post partum and were below $3 \mathrm{mmol} / \mathrm{l}$ for 39 days for cows that ovulated 20-60 days post partum and for 60 days in those cows that ovulated $60-80$ days post partum. The mean glucose levels were not below $3 \mathrm{mmol} / \mathrm{l}$ in cows that ovulated during the first 20 days post partum. It has been shown that cows with clinical ketosis have lower blood glucose and ovulate later than healthy cows (Eldon et al. 1985, Bjarnason 1986, Eldon et al. 1987). Our results suggest that low blood glucose levels early post partum, due to negative energy balance, are probably the cause of subclinical and clinical ketosis which again leads to delayed onset of ovarian activity. This is further supported by the fact that the samples taken 90 days or later, with lower mean values for all four blood parameters than the samples taken earlier post partum, came from anoestrous cows.

It is, however, difficult to reconcile this explanation with the fact that the levels of blood glucose were positively correlated with the time of conception, especially in samples taken during the first 10 days post partum. Cows that conceived 40-59 days post partum had a mean glucose level of 2.8 mmol/1 and cows that conceived 120 days post partum or later had a mean glucose le- 
vel of $3.4 \mathrm{mmol} / \mathrm{l}$. We have no explanation for this contradiction. There was no significant correlation between the levels of the blood parameters and the number of AI per animal. Hignet \& Hignet (1951) found a direct positive correlation between the feeding of $\mathrm{Ca}$ and conception rate and Morrow et al. (1969) reported that liberal feeding of concentrates increased the number of services needed per conception.

The levels of the blood parameters did not seem to have any correlation with the length or amplitude of progesterone of the first post partum ovarian cycle. We conclude that one of the cause of the relatively late onset of ovarian activity in Icelandic dairy cows it a negative energy balance (low blood glucose levels) early post partum which leads to subclinical or clinical ketosis and probably to delayed ovarian activity. Changes in blood glucose and urea values that could possibly affect the reproductive performance of the cow are best seen during the first 1015 days post partum.

\section{Acknowledgement}

We thank Prof. H. Kindahl, at the Department of Obstetrics and Gynaecology, Swedish University of Agricultural Sciences, and Dr. G. Georgsson, Institute for Experimental Pathology, Keldur, for reviewing the manuscript. This study was supported by the Icelandic Science Fund and the International Atomic Energy Agency.

\section{References}

Bjarnason B: Ketose hos malkeköer i Austur-Skaftafellssýsla vinteren 1984-1985 (Ketosis in dairy cows in the East-Skaftafell Commune during the winter 1984-1985). Dansk VetTidsskr. 1986, 69, 881-889.

Butler WR, Everett $R W$, Coppock CE: The relationships between energy balance, milk production and ovulation in post partum Holstein cows. J. Anim. Sci. 1981, 53, 742-748.
Eldon J, Olafsson TH, Thorsteinsson TH: A survey of the post partum reproductive performance of dairy cows with fertility problems in southern Iceland. Acta vet. scand. 1985, 26, 431-441.

Eldon J, Olafsson TH: The post partum reproductive status of dairy cows in two areas in Iceland. Acta vet. scand. 1986, 27, 421-439.

Eldon J, Thorsteinsson, TH, Olafsson TH: The concentration of blood glucose, urea, calcium and magnesium in milking dairy cows. J. Vet. Med. A. $1988,35,44-53$.

Hignet SL, Hignet PG: The influence of nutrition on reproductive efficiency in cattle. Vet. Rec. 1951, 63, 603-609.

Howard HJ, Aalseth EP, Adams GD, Bush LJ, McNew $R W$, Dawson LJ: Influence of dietary protein on reproductive performance of dairy cows. J. Dairy Sci. 1987, 70, 1563-1571.

Kappel LC, Ingraham RH, Morgan EB, Zeringue L, Wilson $D$, Babcock $D K$ : Relationship between fertility and blood glucose and cholesterol concentrations in Holsein cows. Amer. J. vet. Res. 1984, 45, 2607-2612.

McClure TJ: Hypoglycaemia, an apparent cause of infertility of lactating cows. Brit. vet. J. 1968, 124, 126-130.

Morrow DA, Tyrell HF, Trimberger GW: Effects of liberal concentrate feedingt on reproduction in dairy cattle. J. Amer. vet. med. Ass. 1969, 155, 1946-1954.

Olafsson G, Sigurdarson S, Thorsteinsson TH: Súrdoð̃i og fóðrun um burô um burơ (Ketosis and feeding at calving). Freyr. 1974, 70, 429-431.

Oltner R, Edqvist L-E: Progesteron i mjölk (Progesterone in milk). In »Progesteron i mjölk«. SHS Communication no. 101, 1980, 4-28.

Oltner R, Edqvist L-E: Progesterone in defatted milk: Its relation to insemination and pregnancy in normal cows as compared with cows on problem farms and individual problem animals. Brit. vet. J. 1981, 37, 78-87.

Payne JM, Leech FB: Factors affecting plasma calcium and inorganic phosphorus concentrations in the cow with particular reference to pregnancy, lactation and age. Brit. vet. J. 1964. 120, 385388.

Saarinen P: A statistical study of the effect of excessive feeding of calcium and phosphorus supple- 
ments on the blood calcium and phosphorus of dairy cows. J. Sci. Agr. Soc., Finnland, 1950, 10, 122-131.

Sigurdarson S, Thorsteinsson TH: Krammpadoði, bráôadauỡi og magnesinskortur (Grass tetany, sudden death and hypomagnesaemia). In: J. Jónsson ed. Handbók Bænda. Búnaðarfélag Íslands 1978, p. 279-281.

SPSS Inc.: SPSS-X Users Guide. 2nd ed. McGraw Hill Book Company, New York, 1983.

Tainturier D, Braun JP, Rico AG, Thouvenot JP: Variations in blood composition in dairy cows during pregnancy and after calving. Res. Vet. Sci. 1984, 37, 129-131.

Visek WJ: Ammonia: Its effects on biological systems, metabolic hormones, and reproduction. J. Dairy Sci. 1984. 67, 481-498.

\section{Sammenfattning}

Relationen mellan blod och fertilitetsparametrar hos mjölkkor efter partus.

Tidpunkten för ny äggstocksaktivitet efter partus, antalet konstgjorda inseminationer (ai) och tidpunkten för konception registrerades hos 412 isländska mjölkkor under en 3 ảrs tid. Blod insamlades frản djur vid olika tider efter kalvning och serumkoncentrationen av glukos, urea, kalcium (Ca) och magnesium $(\mathrm{Mg})$ analyserades.

Signifikanta positiva korrelationer erhölls mellan nivảer av glukos och $\mathrm{Ca}$ och antal dagar från kalvning. Signifikanta negativa korrelationer erhölls mellan nivå av urea och tiden för första ovulation efter partus. Signifikanta positiva korrelationer hittades mellan nivån av glukos och tidpunkten för konception. Ingen korrelation syntes mellan blodparametrar och antalet ai per djur, längden av första brunstcykeln efter partus eller mängden av progesteron som uppmättas under cyclus.

Resultaten visade en klar, även om inte statistiskt signifikant, benägenhet till en negativ korrelation mellan nivåer av glukos och tidpunkten för första ovulation efter partus.

Våra resultat visar att niváer av glukos och urea kort tid efter förlossningen antyder tidpunkten för början av ny äggstocksaktivitet efter partus. Våra fynd visar att lága blodglukos och ureavärden kort tid efter partus leder till subklinisk eller klinisk ketos vilket kan avsevärt försena början av äggstocksaktiviteten.

(Received February 16, 1988).

Reprints may be requested from: Jðn Eldon, Institute of Experimental Pathology, P. O. Box 8540, Is-128 Reykjavik, Iceland. 
